\title{
Genetic mapping of fiber color genes on two brown cotton cultivars in Xinjiang
}

\author{
Lixiang Wang ${ }^{1,5 \dagger}$, Haifeng $\mathrm{Liu}^{2 \dagger}$, Xueyuan $\mathrm{Li}^{3}$, Xiangwen Xiao ${ }^{1,2}$, Xiantao $\mathrm{Ai}^{3}$, Cheng $\mathrm{Luo}^{2}$, Lihuang Zhu ${ }^{4^{*}}$ \\ and Xiaobo $\mathrm{Li}^{1 *}$
}

\begin{abstract}
In the present study, genetic linkage analysis was carried out to map the fiber color loci $L C_{1}$ and $L C_{2}$ on two brown cotton cultivars with SSR and EST-SSR markers in the reference map by $F_{2}$ segregation populations. The $L c_{1}$ locus carried by Xincaimian6 (Gossypium hirsutum L.) was flanked by the marker NAU2862 and NAU1043 on the long arm of Chromosome 07, with genetic distance $7.8 \mathrm{cM}$ and $3.8 \mathrm{cM}$, respectively. The $L C_{2}$ carried by Xincaimian 5 (Gossypium hirsutum L.) was flanked by the marker NAU5433 and NAU2968 on the short arm of Chromosome 06, with genetic distance 4.4 CM and 7.4 CM respectively. Moreover, the marker NAU3735 and marker NAU5434 Co-segregated with the $L C_{1}$ and the $L C_{2}$ locus, respectively. The results of marker association studies with these two loci provides the basic information for the final isolation of these important genes in colored cotton, and these linkage markers also could facilitate application of marker assisted selection in the future.
\end{abstract}

Keywords: Colored cotton; Genetic mapping; SSR

\section{Background}

Naturally colored cotton, or colored cotton, appears as brown or green colored fiber during the fiber development process. Requiring no or less dying in the textile processing, colored cotton reduces the pollution to the environment; moreover, free from residual chemical toxicant, garments made from colored cotton are more comfortable, softer and healthier for human bodies (Yuan et al. 2012). However, colored cotton is generally inferior to white cotton, especially with respect to fiber quality, including shorter, weaker fiber and lower micronaire. There is typically a negative correlation between fiber color and fiber quality traits mainly due to the pleiotropic effects of fiber color genes. For example, the deeper fiber color is, the lower the fiber quality. It is a challenge for researchers and breeders to break the negative correlation between the fiber color and fiber quality. Mapping and cloning of fiber color genes should

\footnotetext{
* Correspondence: Ihzh@genetics.ac.cn; xiaoboli@ms.xjb.ac.cn

${ }^{\dagger}$ Equal contributors

${ }^{4}$ State Key Laboratory of Plant Genomics, Institute of Genetics and Developmental Biology, Chinese Academy of Sciences, Beijing 100101, China ${ }^{1}$ Key Laboratory of Chemistry of Plant Resources in Arid Regions, Xinjiang Technical Institute of Physics and Chemistry, Chinese Academy of Sciences, Urumqi 830011, China

Full list of author information is available at the end of the article
}

substantially give a clue to resolve that problem mentioned above.

Kohel carried out traditional genetics research on some brown cotton materials collected from all over the world and discovered that brown fiber was controlled by six loci $\left(L c_{1} \sim L c_{6}\right) . L c_{1}$ and $L c_{2}$ control the brown color of lint, $L c_{3}$ controls dark brown, $L c_{4}, L c_{5}$ and $L c_{6}$ control the light brown. Furthermore, he assigned $L c_{1}$ to chromosome 7 and $L c_{2}$ to chromosome 6 by linkage to morphological markers (Kohel 1985). In this study, we aimed to map $L c_{1}$ and $L c_{2}$ loci to a detailed reference molecular map (Rong et al. 2004). Complete diallel cross between four white cotton cultivars (Xinluzao13, Xinluzao31, Zhongmiansuo41 and Zhongmiansuo45) (Gossypium hirsutum L.) and two elite brown cotton cultivars (Xincaimian5 and Xincaimian6) (Gossypium hirsutum L.) cultivated in Xinjiang were conducted, and sixteen populations were obtained. Furthermore, we used the mapping populations which were in accordance with the 3:1 Mendelian inheritance $\left(\chi_{0.05}^{2}<3.84, \mathrm{df}=1\right)$ to locate the $L c_{1}$ and $L c_{2}$ genes in the cotton reference map. This research is a start point for further defining a finer location of the fiber color genes that may result in the eventual cloning of these genes by map-based and candidate gene approaches.

\section{实 Springer}

(c) 2014 Wang et al.; licensee Springer. This is an Open Access article distributed under the terms of the Creative Commons Attribution License (http://creativecommons.org/licenses/by/4.0), which permits unrestricted use, distribution, and reproduction in any medium, provided the original work is properly credited. 


\section{Materials and methods Plant materials}

In the summer of 2007, parental lines (Table 1) were crossed in all combinations including reciprocals. The $\mathrm{F}_{1}$ plants were self-pollinated to produce the $F_{2}$ populations in the second year. In the summer of 2009, a total of sixteen $F_{2}$ populations were grown, and field evaluation and genetic analysis were undertaken. All field experiments were carried out in Korla Breeding Base of China Colored-Cotton (Group) Co., Ltd.

\section{Cotton DNA extraction}

The genomic DNA from the parental cultivars or lines and their $F_{2}$ segregating populations were extracted from the young leaves by the CTAB method (Paterson et al. 1993; Zhang et al. 2000).

\section{SSR-PCR analysis and genetic mapping}

Sixty-five and seventy-one pairs of cotton simple sequence repeat (SSR) primers on Chromosome 06 and Chromosome 07 were chosen according to primer information published on Cotton Marker Database (CMD) (http://www.cottongen.org/data/markers). PCRs were performed using a PTC-200 (Bio-Rad, Hercules, CA, USA) thermocycler. The genotype of the white parent was scored as "1", the brown parent and the heterozygous $\left(F_{1}\right)$ genotype were scored as " 2 " and " 3 " in the parents, $F_{1}$ and $F_{2}$ populations. Missing data were noted as "-". The $x^{2}$ test for goodness of fit was used to assess the Mendelian dominant inheritance in the $\mathrm{F}_{2}$ segregating population. After eliminating the segregation distortion markers by $\chi^{2}$ test, other SSR markers were detected by linkage analysis.

The volume of PCR reaction system was $20 \mu \mathrm{l}$, including $2 \mu \mathrm{l}$ of $10 \times$ PCR buffer (containing $\mathrm{Mg}^{2+}$ ), $1 \mu \mathrm{l}$ of dNTPs $(10 \mathrm{mM}), 0.3 \mathrm{U}$ of Taq enzyme $(2 \mathrm{U} / \mu \mathrm{l}), 0.5 \mu \mathrm{l}$ of SSR upstream primers and downstream primers $(5 \mu \mathrm{M})$ and $1 \mu \mathrm{l}$ of template DNA $(40 \mathrm{ng} / \mu \mathrm{l}), 14.7 \mu \mathrm{l}$ of $\mathrm{ddH}_{2} \mathrm{O}$. Reaction procedures were $94^{\circ} \mathrm{C}$ for $4 \mathrm{~min} ; 94^{\circ} \mathrm{C}$ for $40 \mathrm{~s}$, $57^{\circ} \mathrm{C}$ for $45 \mathrm{~s}, 72^{\circ} \mathrm{C}$ for $50 \mathrm{~s}, 35$ cycles; $72^{\circ} \mathrm{C}$ for $10 \mathrm{~min}$, and the amplified products were preserved at $4^{\circ} \mathrm{C}$. Amplified sample was mixed with $10 \mu \mathrm{l}$ of loading buffer, denatured at $95^{\circ} \mathrm{C}$ for $10 \mathrm{~min}$, the mixture was immediately transferred to ice-bath cooling for electrophoresis. Vertical slab denaturing polyacrylamide gel (7\%) electrophoresis was used to separate the SSR amplified products, pre-electrophoresis at $120 \mathrm{~V}$ for $10 \mathrm{~min}$, and $180 \mathrm{~V}$ constant voltage electrophoresis for $4 \mathrm{~h}$. DNA fragments were detected with ethidium bromide staining.

\section{Data analysis}

SPSS13.0 software was used to test for segregation ratio of selected markers in $F_{2}$ segregating population and Mapmaker 3.0 software was employed to construct the genetic linkage map, and all linkage groups were determined at LOD scores $\geq 6$. Mapping was completed using MapDraw software (Lander et al. 1987).

\section{Results}

\section{Inheritance of fiber color}

In each population, all plants in the $\mathrm{F}_{1}$ generation displayed the same phenotype as the brown parent. This result indicates that the brown fiber trait was determined by nuclear inheritance and brown was dominant over white. Segregation analysis of $F_{2}$ segregation populations was accomplished by visual inspection of the lint color of individual plants in each population. Five $F_{2}$ populations were consistent with a 3:1 ratio at significant level of $\alpha=0.05$ (Table 2). Therefore, these five populations were used for mapping. Totally, 65 and 71 SSR markers on Chromosome 06 and Chromosome 07 respectively were employed to screen polymorphisms among all six parental lines. Sixteen polymorphic marker loci, 9 on Chromosome 06 and 7 on Chromosome 07, were identified. Then, the polymorphic SSR markers between the two parental lines were run on the corresponding $F_{2}$ populations and the marker genotypes were recorded. The mapping results were shown as follows.

\section{Genetic mapping of $L c_{1}$}

Linkage analysis suggested that the fiber color gene carried by Xincaimian6, $L c_{1}$, is preliminarily located between NAU3654 and MS58 on the long arm of Chromosome 07 , based on analysis of three $F_{2}$ populations derived from Zhongmiansuo41 $\times$ Xincaimian6, Xincaimian6 $\times$ Xinluzao31 and Xinluzao31 $\times$ Xincaimian6. To narrow

Table 1 The information of parental lines for constructing the $F_{2}$ populations

\begin{tabular}{cccc}
\hline Lint phenotype & Cultivars & Fiber color & Material source \\
\hline \multirow{2}{*}{ Brown } & Xincaimian5 & Dark brown & China Colored-Cotton Group \\
& Xincaimian6 & Light brown & China Colored-Cotton Group \\
& Xinluzao13 & White & Nongqishi Agricultural Research Institute of XPCCs \\
White & Xinluzao31 & White & Xinjiang Kuitunwanshi Seed Industry \\
& Zhongmiansuo41 & White & Cotton Research Institute of China \\
& Zhongmiansuo45 & White & Cotton Research Institute of China \\
\hline
\end{tabular}


Table 2 White/brown cross combinations consisted with Mendel segregation ratio

\begin{tabular}{|c|c|c|c|c|c|}
\hline \multicolumn{2}{|c|}{ Parental combination } & \multicolumn{2}{|c|}{$f_{2}$} & \multirow{2}{*}{$\begin{array}{l}\text { Brown: } \\
\text { white }\end{array}$} & \multirow[t]{2}{*}{$x^{2}$} \\
\hline$P_{1}\left(\sigma^{7}\right)$ & $P_{2}(q)$ & White & $\overline{\text { Brown }}$ & & \\
\hline Xinluzao13 & Xincaimian6 & 30 & 85 & $2.83: 1$ & 0.072 \\
\hline Xinluzao31 & Xincaimian6 & 27 & 82 & $3.07: 1$ & 0.012 \\
\hline Zhongmiansuo41 & Xincaimian6 & 27 & 90 & 3.33:1 & 0.231 \\
\hline Zhongmiansuo45 & Xincaimian6 & 36 & 84 & 2.33 .1 & 1.600 \\
\hline Xincaimian6 & Xinluzao13 & 25 & 78 & $3.12: 1$ & 0.029 \\
\hline Xincaimian6 & Xinluzao31 & 26 & 76 & $2.92: 1$ & 0.013 \\
\hline Xincaimian6 & Zhongmiansuo41 & 17 & 100 & $6: 1$ & - \\
\hline Xincaimian6 & ansuo45 & 23 & 90 & 1 & - \\
\hline Xinluzao13 & Xincaimian5 & 40 & 72 & $1.8: 1$ & - \\
\hline Xinluzao31 & Xincaimian5 & 20 & 79 & $3.95: 1$ & - \\
\hline Zhongmiansuo41 & Xincaimian5 & 34 & 93 & $2.74: 1$ & 0.08 \\
\hline Zhongmiansuo45 & Xincaimian5 & 11 & 88 & $8: 1$ & - \\
\hline Xincaimian5 & Xinluzao13 & 37 & 81 & $2.19: 1$ & - \\
\hline Xincaimian5 & Xinluzao31 & 28 & 92 & $3.32: 1$ & 0.223 \\
\hline Xincaimian5 & Zhongmiansuo41 & 17 & 100 & $5.88: 1$ & - \\
\hline Xincaimian5 & Zhongmiansuo45 & 23 & 96 & $4.17: 1$ & - \\
\hline
\end{tabular}

Note: $X_{0.05}^{2}=3.84, \mathrm{df}=1$. Bold numbers represent $F 2$ populations which were used for linkage analysis and genetic mapping of Lc1 and Lc2.

down the $L c_{1}$ locus region further, three SSR markers, NAU2862, NAU3735 and NAU1043, were detected as DNA polymorphisms between Xincaimian6 and Xinluzao31 (Figure 1A). $L c_{1}$ co-segregated with the marker NAU3735, and flanked by markers NAU2862 and
NAU1043, with genetic distance of $7.8 \mathrm{cM}$ and $3.8 \mathrm{cM}$, respectively (Figure $2 \mathrm{~A}$ ).

\section{Genetic mapping of $L c_{2}$}

Linkage analysis also suggested that the fiber color gene carried by Xincaimian $5, L c_{2}$, is preliminarily located between CIR329 and NAU905 in the short arm of Chromosome 06 by $\mathrm{F}_{2}$ populations derived from Zhongmiansuo41 $\times$ Xincaimian5 and Xincaimian5 $\times$ Xinluzao31. To narrow down the $L c_{2}$ locus region further, four SSR markers, NAU5373, NAU5433, NAU5434 and NAU2968, were detected as DNA polymorphisms between Zhongmiansuo41 and Xincaimian5 (Figure 1B). $L c_{2}$ co-segregated with the marker NAU5434, and flanked by NAU5433 and NAU2968, with genetic distance of $4.4 \mathrm{cM}$ and $7.4 \mathrm{cM}$, respectively (Figure $2 \mathrm{~B})$.

\section{Discussion}

The inheritance of cotton fiber color trait has been studied in several reports and a few of genetic loci potentially involved in fiber color formation have been identified (Harland 1935; Симонгумян 1984; Kohel 1985; Shi et al. 2002). Harland (1935) found that the inter-barbadense cross Egyptian brown $\times$ Sea Island white gave F1 intermediate and complicated segregation of the blending type in $\mathrm{F} 2$ and the factor $\mathrm{K}^{\mathrm{B}}$ ( brown lint) of the brown parent was accompanied by a number of plus modifiers absent in the white parent. He also concluded that brown lint in barbadense and hirsutum was not determined by the same gene, but by a pair of duplicate genes. Симонгулян (1984) made a conclusion through

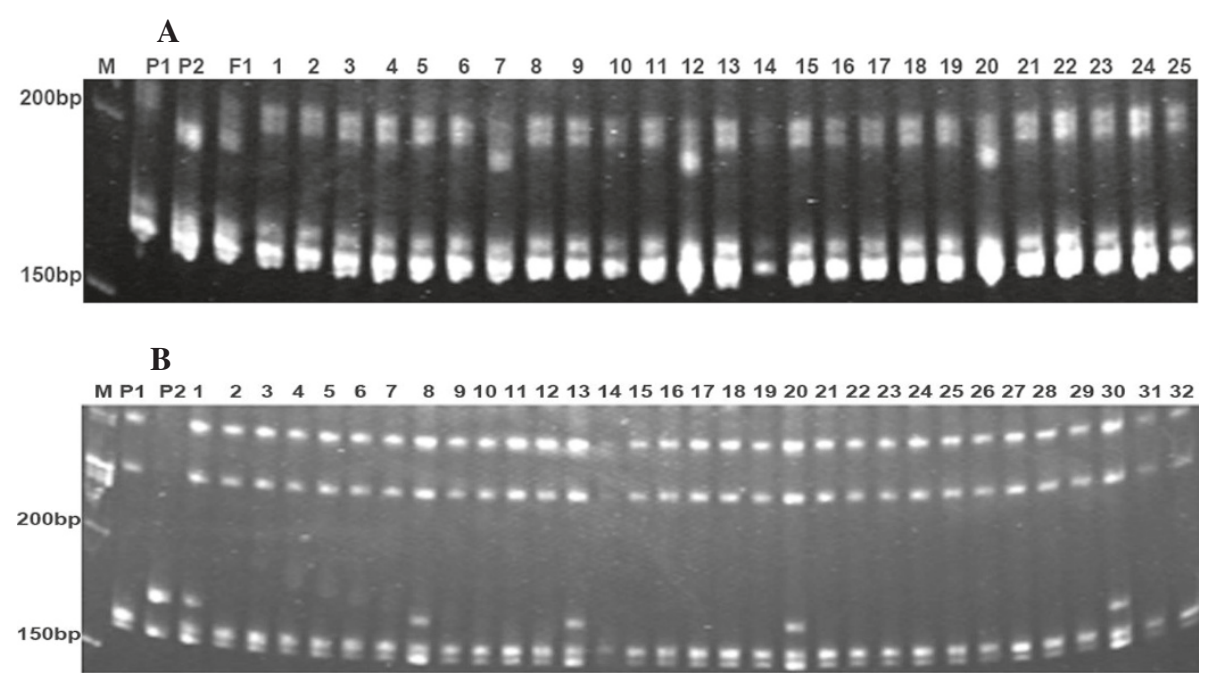

Figure 1 PCR amplification products generated by SSR primer pairs in F2 segregation populations. A. Segregation of SSR marker NAU1043 in $F_{2}$ population from Xincaimian $6 \times$ Xinluzao31. Lane M is a 100-bp molecular weight marker. Lanes 2, 3, and 4 are parental lines Xinluzao31, Xincaimian 6 and $F_{1}$. Lanes 5-25 are a subset of the $F_{2}$ individuals; B. Segregation of SSR marker NAU5433 in $F_{2}$ population from Zhongmiansuo $41 \times$ Xincaimian5. Lane M is a 100-bp molecular weight marker. Lanes 2, 3, and 4 are parental lines Zhongmiansuo41, Xincaimian5 and $F_{1}$. Lanes $5-32$ are a subset of the $F_{2}$ individuals. 

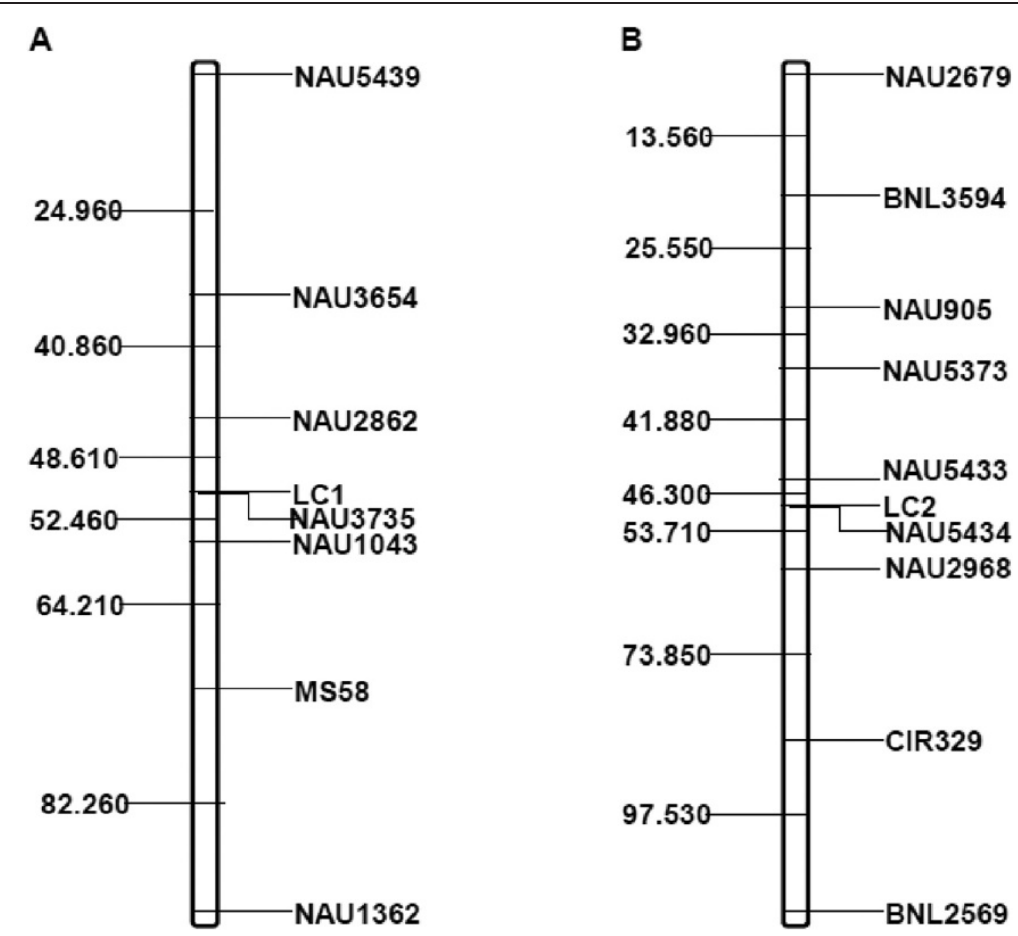

Figure 2 Mapping of $L c_{1}$ and $L c_{2}$. A. Mapping of $L c_{1}$ gene on Chromosome 07; B. Mapping of $L c_{2}$ gene on Chromosome 06.

the analysis of a hybrid between white lint upland cotton and brown semi-wild Mexican species (G. hirsutum) that the brown fiber was controlled by two pairs of complementary major genes $L c_{1}$ and $L c_{2}$, lack of any pair of dominant alleles lint became white in color, and another gene $L c_{3}$ was a supplementary gene which might strengthen the function of these two pairs of genes. Shi et al. (2002) concluded that brown and green colored lint were controlled by one pair of major genes incomplete in dominance on non-homologous chromosomes, and that there were genetic interactions between lint and fuzz coloring genes. Interestingly, in our studies, we noticed that some $\mathrm{F}_{2}$ populations fitted a 3:1 ratio regardless of cross or reverse cross, e.g. a combination of Xinluzao 31 and Xincaimian 6, but some do not, e.g. a combination of Zhongmiansuo 41 and Xincaimian 5 . Therefore, we deduced that modification of minor genes resulted in the difference in proportion of $F_{2}$ in reciprocal crosses.

It has been previously demonstrated that brown cotton varieties in Xinjiang had nearer genetic relationships with upland cotton (G. hirsutum), but far from Seaisland cotton (G. barbadense) (Wang et al. 2012). For many years, breeders have tried to improve the fiber quality of colored cotton by introgressing fiber quality traits from sea island cotton, but the results were poor (Lacape et al. 2005). For map-based cloning, because chromosome variability of target genes can be ensured between upland cotton (G. hirsutum) and sea island cotton (G. barbadense), and genetic map of both cotton species can be fully utilized as well, G. hirsutum $\times G$. barbadense populations are usually chosen in map-based cloning (Park et al. 2005). However, in fact, few progenies of $F_{1}$ were fertile, and severe segregation distortion was observed in $F_{2}$ populations by brown cotton crossing various sea island cultivars. Distant hybridization-sterility between current brown cotton cultivars and Sea-island cotton cultivar is a bottleneck not only for the improvement of fiber quality but also for map-based cloning fiber color genes in colored cotton (Zhang et al. 1994).

Another of the major limitations to map-based cloning for the genes of interest in cotton is the lack of polymorphism resulting from a narrow genetic base. Ling et al. reported that genetic similarities based on Jaccard's similarity coefficient between brown cotton and white upland cotton was an average of 0.7 using sequencerelated amplified polymorphism (SRAP) markers, which suggests that these cultivars are very closely related concerning their genetic background or they have a common ancestor (Ling et al. 2009; Guo et al. 2004). In China, three major cotton growing agro-ecological zones have been divided based on cotton type, distribution and growth environment, including the northwest inland cotton region, the Yellow River valley region and Yangtze River valley region. Presently, according to the pedigrees known, brown cotton cultivars had nearer 
genetic relationships with native upland cotton varieties in Xinjiang than those cultivars in the other two regions. Therefore, the cotton varieties in the other two regions are preferred to choose as parental lines for constructing segregation populations; on the other hand, more markers, such as single nucleotide polymorphism (SNP), cleaved amplified polymorphic sequences (CAPS) markers, need to be developed for further fine mapping. Many studies covering physiology, biochemistry, cell genetics and conventional breeding have been reported using colored cotton as subject materials (Qiu 2004).

In conclusion, we fulfilled the primary purpose of mapping the $L c_{1}$ and $L c_{2}$ loci using SSR markers. These findings could be used for marker-assistant selection breeding. To the best of our knowledge, this is the first effort at mapping fiber color genes of brown cotton cultivars using SSR markers. Fine mapping will be further carried on by enlarging the $F_{2}$ populations constructed by near-isogenic line and developing the new markers. With the more sequences release of tetraploid cotton, final cloning of the fiber color genes would help us to understand the complex molecular mechanism of color development in cotton fiber.

\section{Abbreviations}

SSR: Simple sequence repeats; CMD: Cotton marker database; SRAP: Sequence-related amplified polymorphism; CAPS: Cleaved amplified polymorphic sequences.

\section{Competing interests}

All authors declare that they have no competing interests in regard to this manuscript.

\section{Authors' contributions}

$L W, H L, C L$, and $X X$ carried out the experiments and participated in data analysis. $\mathrm{HL}, \mathrm{XYL}, \mathrm{XA}$, and $\mathrm{CL}$ carried out the collection of materials and statistical analysis. $L Z$ participated in the design of the study. XBL conceived of the study, and participated in its design, coordination and data analysis. LW, XBL and XX wrote the final version of the manuscript. All authors read and approved the final version of the manuscript.

\section{Acknowledgments}

This work was supported by West Light Foundation of the Chinese Academy of Sciences (XBBS201020), Creation Project of Germplasm Resources for Colored Cotton with High Quality (2013AB003), China Postdoctoral Science Foundation (2012 M521827) and National Key Special Fund for Transgenic Cotton (2013ZX08005-005)

\footnotetext{
Author details

${ }^{1}$ Key Laboratory of Chemistry of Plant Resources in Arid Regions, Xinjiang Technical Institute of Physics and Chemistry, Chinese Academy of Sciences, Urumqi 830011, China. ${ }^{2}$ China Colored-Cotton (group) Co., Ltd., Urumqi 830016, China. ${ }^{3}$ Economic Crop Research Institute, Xinjiang Academy of Agricultural Sciences, Urumqi 830091, China. ${ }^{4}$ State Key Laboratory of Plant Genomics, Institute of Genetics and Developmental Biology, Chinese Academy of Sciences, Beijing 100101, China. ${ }^{5}$ Present address: Key State Laboratory of Plant Cell \& Chromosome Engineering Center of Agricultural Resources Research, Institute of Genetics and Developmental Biology, Chinese Academy of Sciences, 286 Huaizhong Road, Shijiazhuang, Hebei 050021, China.
}

\section{References}

Guo JY, Wang YQ, Wu MG, Zhang LM, Liu FJ, Li WB, Liu HF, Zhao TP, Sun YR (2004) Genetic diversity analysis of brown cotton and green cotton. Hereditas 26:63-68

Harland SC (1935) The genetics of cotton Part XIV The inheritance of brown lint in new world cottons. J Genet 31:27-37

Kohel RJ (1985) Genetic analysis of fiber color variants in cotton. Crop Sci 25:793-797

Lacape JM, Nguyen TB, Courtois B, Belot JL, Giband M, Gourlot JP, Gawryziak G, Roques S, Hau B (2005) QTL analysis of cotton fiber quality using multiple $\times$ backcross generations. Crop Sci 45:123-140

Lander ES, Green P, Abrahamson J, Barlow A, Daly MJ, Lincoln SE, Newburg L (1987) MAPMAKER: an interactive computer package for constructing primary genetic linkage maps of experimental and natural populations. Genomics 1:174-181

Ling L, Li T, Li Z, Cai Y, Sun X, Su X, Lin Y, Cai Y (2009) Genetic difference analysis between colored cotton and white cotton by SRAP markers. Chin Agric Sci Bull 25:32-38

Park YH, Alabady MS, Ulloa M, Sickler B, Wilkins TA, Yu J, Stelly DM, Kohel RJ, El-Shihy OM, Cantrell RG (2005) Genetic mapping of new cotton fiber loci using EST-derived microsatellites in an interspecific recombinant inbred line cotton population. Mol Genet Genomics 274:428-441

Paterson AH, Brubaker C, Wendel JF (1993) A rapid method for extraction of cotton (Gossypium spp.) genomic DNA suitable for RFLP or PCR analysis. Plant Mol Biol Rep 11:122-127

Qiu X (2004) Research progress and prospects on naturally-colored cotton. Cotton Sci 16:249-254

Rong J, Abbey C, Bowers JE, Brubaker CL, Chang C, Chee PW, Delmonte TA, Ding X, Garza JJ, Marler BS, Park C, Pierce GJ, Rainey KM, Rastogi VK, Schulze SR, Trolinder NL, Wendel JF, Wilkins TA, Williams-Coplin TD, Wing RA, Wright RJ, Zhao X, Zhu L, Paterson AH (2004) A 3347-locus genetic recombination map of sequence-tagged sites reveals features of genome organization, transmission and evolution of cotton (Gossypium). Genetics 166:389-417

Shi YZ, Du XM, Liu GQ, Qiang AD, Zhou ZL, Pan ZE, Sun JL (2002) Genetic analysis of naturally colored lint and fuzz of cotton. Cotton Sci 14(4):242-248

Wang L, Liu H, Xiao X, Pang Z, Song W, Lu C, Luo C, Liu G, Xu J, Li XB, Li X (2012) Studies on hereditary properties of colored cotton in Xinjiang. Agric Sci Technol 13:541-546

Yuan S, Malik W, Hua S, Bibi N, Wang X (2012) In vitro inhibition of pigmentation and fiber development in colored cotton. J Zhejiang Univ Sci B 13:478-486

Zhang J, Gong Z, Sun J, Liu J (1994) Heterosis of yield and fiber performance in interspecific crosses between Gossypium hirsutum and G. barbadense. Acta Gossypii $\operatorname{Sin}$ 6:140-145

Zhang J, Wu YT, Guo WZ, Zhang TZ (2000) Fast screening of microsatellite markers in cotton with PAGE/silver staining. Acta Gossypii Sin 12:267-269

Симонгулян НГ (1984) Genetic analysis of fiber color in upland cotton. Agron Abroad: Cotton 3:172-191

doi:10.1186/2193-1801-3-480

Cite this article as: Wang et al:: Genetic mapping of fiber color genes on two brown cotton cultivars in Xinjiang. SpringerPlus 2014 3:480.

\section{Submit your manuscript to a SpringerOpen ${ }^{\mathcal{D}}$ journal and benefit from:}

- Convenient online submission

- Rigorous peer review

- Immediate publication on acceptance

- Open access: articles freely available online

- High visibility within the field

- Retaining the copyright to your article

Submit your next manuscript at $>$ springeropen.com 